\title{
Evaluation of Tax Payment Risks in Whole of Tax System
}

\author{
Artūras Mažeika1, Aelita Skaržauskienè ${ }^{1}$, Modestas Kaseliauskas², Ramūnas \\ Mackevičius $^{3}$, Valdas Buginskis ${ }^{3}$, Gerda Mackevičiene $\dot{ }^{4}$ and Dalè Dzemidiené ${ }^{1}$ \\ ${ }^{1}$ Mykolas Romeris University, Vilnius, Lithuania \\ ${ }^{2}$ State Tax Inspectorate, Vilnius, Lithuania \\ ${ }^{3}$ Vilnius University, Kaunas faculty of Humanities, Kaunas, Lithuania \\ ${ }^{4}$ Kaunas University of Technology, Kaunas, Lithuania
}

\begin{abstract}
Economic sectors of sail and repair of motor vehicles should be considered as specific and important for Lithuanian economy as they encourage economic growth in different regions. Used cars' market in Kaunas is the biggest in the European Union. On the other hand, this economic sector is one of the most risky sectors in terms of informal economy. During economic growth slowdown and even recession, more control of informal economy is needed. That's why it is meaningful to create and implement effective risk e-management models that would help tax authorities and audit companies to identify the risks of taxpayers operating in mentioned economic branches. These models would allow reacting to changes in degrees of brunch economy and risks operatively by determining strategies and measures to influence unwanted results.
\end{abstract}

Keywords: e-evaluation of risk, tax evasion risk, e-databases, cars business, informal economy, aggregated model of the control of the whole of tax system.

\section{Introduction}

Social responsibility, according to the different units that function in the society and affect one another, is one of the most pressing and multiple problems which have an adverse impact on the sustainable development of the society and the overall quality of life. Social responsibility of individuals, social responsibility of communities and social responsibility of public-sector, as the importance and benefits issues of the functioning units in the the society and the cooperation of stakeholders, were analyzed by Hamann 2003), Acutt,(2003),O'Riordan (2008), Fairbrass, (2008), Korhonen (2003), Fray, (2007), Schouten (2007), Eberhard-
Harribey (2006) and Mittal et al. (2008), Zairi (2002), Peters (2002), Prior (2008) Argandoña (2008), the levels of the social responsibility's of national corporates and their influence on the overall development of countries were revealed in the investigations of Alas (2007), Tafel (2007), Cork (2005) Juholin (2004), Pētersons (2008), Kring (2008).

In their studies, Lithuanian authors Jusčius (2009, 2008), Ciegis (2005), Grundey (2009) Guzavičius (2009), Snieška (2008) examined the issues of the social responsibility in business organizations, emphasized the importance of decreasing value gap of business organizations and stakeholders and revealed the importance

Copyright (C) 2011 Artūras Mažeika, Aelita Skaržauskienė, Modestas Kaseliauskas, Ramūnas Mackevičius, Valdas Buginskis, Gerda Mackevičienė and Dalè Dzemidienè. This is an open access article distributed under the Creative Commons Attribution License unported 3.0, which permits unrestricted use, distribution, and reproduction in any medium, provided that original work is properly cited. Contact author: Artūras Mažeika E-mail: arturasm@mruni.eu 
and the need of developing ethical principles and social responsibility in organizations for sustainable development. The risk management implications, different factors of management and business processes and other problematical aspects related to the risk management were investigated by Lando (2009); O'Neil (1992), Egan, (1992), Hood (1999), Kelly (1999), Mackay (2000), Sweeting (2000), Rupsys (2008) Mažeika (2009), Buginskis (2009), Petrauskas (2009), Šatkauskas (2009) and others. Tax and fiscal systems analysis, the audit selection system studies were conducted by Genet (2009), Tugui (2009) Mackevičius (1999), Stačiokas (2003), Rimas (2000) and others. Lithuanian tax system's integration and harmonization with the European Union system were studied by Stačiokas (2003), Buškevičiūtè (2003), Rimas (2000), Novosinskienè (2000), Mažeika (2008).

The impact of black economy to all system of economy was examined by Navickas (2003), Mažeika (2008). The problems of audit selection, that reflect a riskassessment modeling, were analysed by Kabašinskas, Toliatienè (1997), Mackevičius (1999), tačiokas and Rupšys (2003) and others. However, the insufficient attention was paid to the analysis of risk factors, the analysis of selection methods, the risk-model making and high-risk taxpayers' identification.

Research object:

- The impact of e. evaluation model of value added tax (hereinafter - VAT) evasion risks to vehicle sales and repair business sector identifying high-risk taxpayers under the tax evasion probability.

Research aim:

- To create and to test aggregated model of the control of the whole of tax system, consisting e. evaluation model of tax, process of identification of tax risk and way of analysis of the structure of the taxation system. Suggested model is tested in risky vehicle sales and repair economical business sector. Usage of the model is aimed to base efficiency of e. data use from different sources of information identifying high-risk taxpayers according to the likelihood of tax payment evasion.

Research methods:

- The scientific literature analysis, modeling, statistical data processing, empirical conclusion making.

The research results present possibilities of analysis of the tax system, identification of greatest risk and suggestion of the appropriate control measures. Suggested e. evaluation model reveals capabilities to use data from different sources of information in the operations of tax administrator. The model of tax risk identification and assessment and the example of practical application discloses the efficiency of the scientific models' use and base the need and usefulness of such studies. It reveals the potential to make the tax analysis and assessment in the case of tax evasion in motor vehicle's sales and repair sector which is an important Lithuanian economic sector. It is given the possibilities to adapt the model of the risks e. evaluation in the operations of tax administration, controlling the collection of taxes, in particular, value-added tax, from mentioned economic sector. It will help to improve the business environment of SMEs and to overcome the economic crisis, to promote the healthy competition and to eliminate the factors of the black economy.

\section{Country's Taxation System and Its Analysis Methods}

On the basis of studies and the results of good practice, the authors suggest the new system of taxpayers' taxation and tax risk (see Figure 1) that is used in the modern IT management processes. The main novelties of suggested system are three main constituent subsystems / processes that are segmented, systematic and sorted according to the significance. They are taxpayer taxation, tax legal regulation and its administration processes. Implementing the regulation of the tax system (basic steps are showed in the aims area of the 
suggested model), the evaluation and testing are integral and necessary conditions for the successful operation of the system. Analyzing different taxes and their economic effects, the authors suggest analyzing different system's sections, distinguishing the analysis according to subjects' size and the assessment of economic activity as the fundamental analysis. Subsystem and process of legal regulatory according to the suggested model includes national legislation monitoring, analysis and development. The compatibility and regulatory of the national and the EU legislation are extremely significant. The analysis of tax administration's subsystem is the main part of the suggested model. Using the control tools and processes set of tax administrator that is suggested further (see Figure 2), in this part problematic areas can be identified. In addition, using the management and evaluation model of tax risk (see Figure 6), the most effective decision making method can be found. All processes of tax system's parts and their results (assessment and studies) are interdependent closely, and their results affect each other significantly.

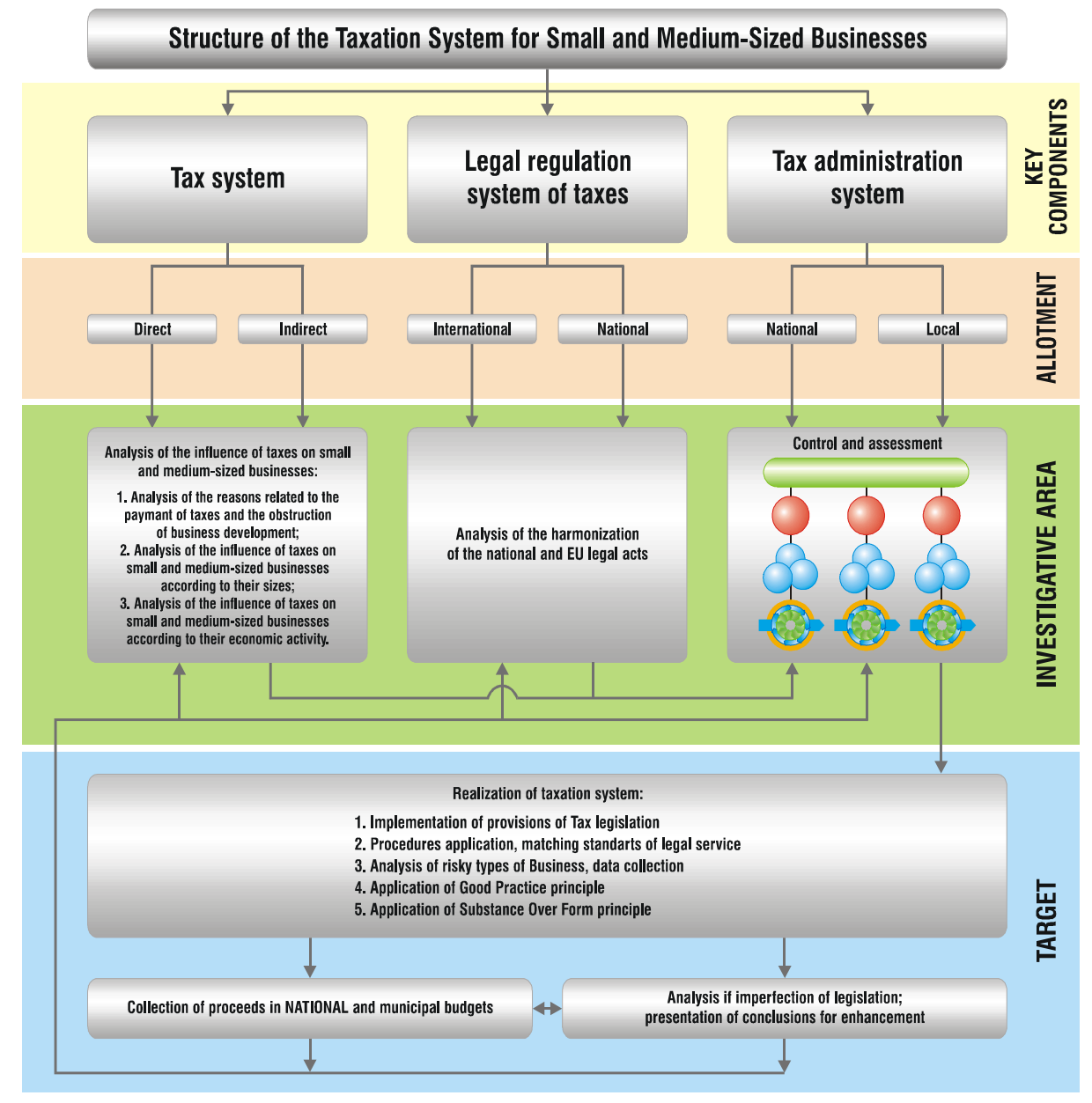

Fig. 1. The System of Taxation and Tax Risk

\section{Black Economy and its Factors}

The studies about the black economy and the ways to fight against it have been carried out by these Lithuanian and foreign authors: Novosinkaite (2000), Opole (2008), Staliuniene (2009), Kundeliene (2009), Lee D. Parker (2006), and others. 
The significance of appropriate solutions of control function is emphasized in those studies, but there is no perfect model offered that would help to ensure the operation of country's tax administration system (under crisis conditions). In the basis of recent STA studies, the black economy in Lithuania is $25-32$ percent of the country's GDP. This level was largely covered by the country's economic downturn because of the global economic crisis, resulting in the growth of a large part of the uncontrolled business activities. The creation of a functional and efficient control mechanism of the black economy becomes one of the main challenges of countries' authorities to curb the black economy.

Complex model, suggested by authors, consists of three parts. It valuates and analyses taxation system of the country, identification of tax risk and management of taxation risks at the lowest level of control system. Suggested model is more efficient tool for shadow economy control at the national and international levels.

\section{Adoptation of the Tax Model of Risk Management in Whole of Tax System}

In order to optimize and improve the operation of the country's total tax system and the control (see Figure 1), the authors suggest a principled decision the segmentation of national tax system. This approach is designed for specific segments of the tax system to provide the specific and unique sequence of risk management actions. The tax risk identification process that is suggested by the authors is shown in Figure 2.

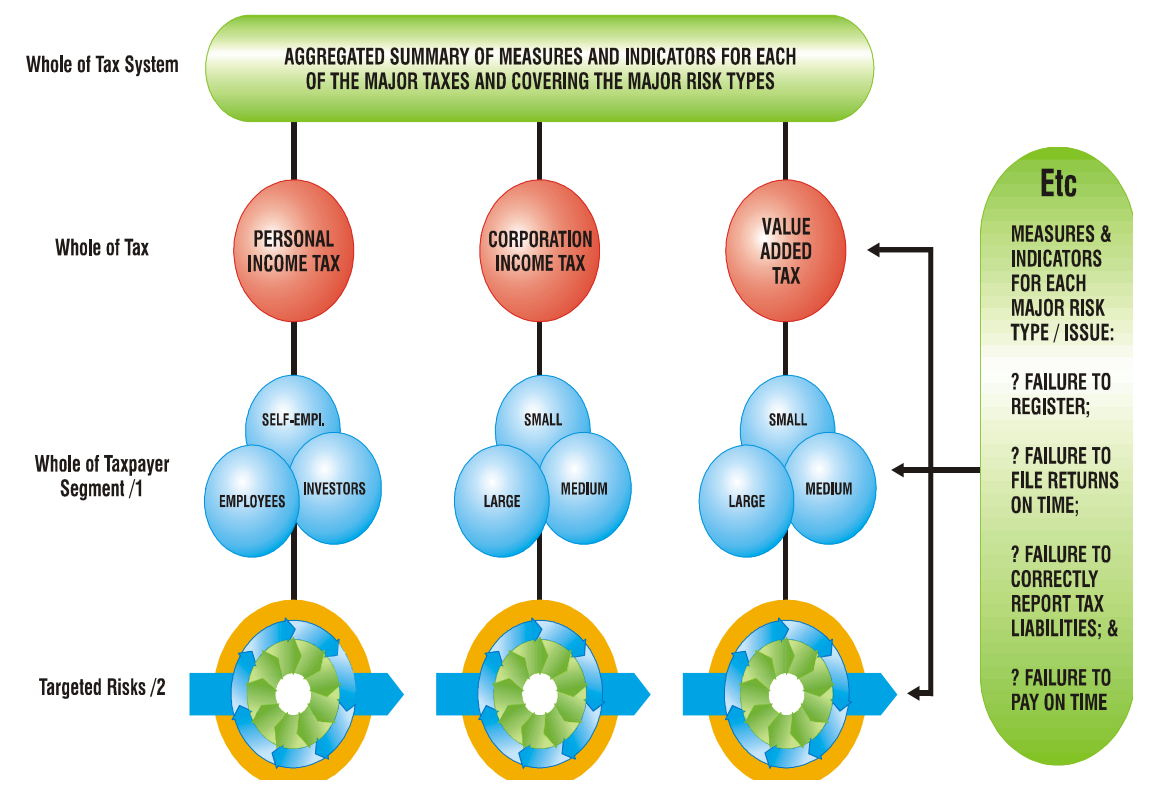

Fig 2. Suggested Process to Identify Tax Risk

It is seen that the whole tax system is divided into two cuts by splitting it according to both the nature of the tax and the level of the tax control. In accordance with the nature of the tax system, it is appropriate to distinguish three sections:

- personal income taxes,

- the income taxes of legal persons and
- indirect taxes (VAT and excise duties)

This division is suggested on the basis of the evaluation of progressive tax systems in foreign countries and the latest and most relevant studies and recommendations of the European Union regulatory authorities. Each of these areas of the tax system has its own specific tax features, which should be taken into account creating specific control 
mechanism. The specificity of the control mechanism development is reflected by another division of the tax system, namely its isolation to the individual control levels. As it can be seen from the left column in the scheme in Figure 2, the model on the upper or the first-level breaks the system in the level of the different tax domains. On the second level, the taxpayers' segmentation is carried out within each tax areas. The authors suggest dividing individuals into employed workers, individuals engaged on individual activities and investors. It is suggested to segment legal persons' income and indirect taxation according to the size of the taxpayers excluding small, medium and large taxpayers. In the final stage of the tax system, it is suggested the control model for every control pattern of the smallest segments of the taxpayers on the basis of the assessment model of the taxpayers' risk (see Figure 6).Depending on the tax group and the controlled taxpayers' segment, the unique and specifically targeted control actions that are presented in the further sections are adapted for each sample.

\section{Review of Taxpayers' Business in Vehicle Sale, Repair and Technical Maintenance Business}

The social responsibility of organizations is associated with the totality of values, issues and processes that organizations must pay attention to in order to minimize any harm resulting from their activities and create economic (profit), social (people) and environmental (planet) value (Schouten, 2007). Juholin (2004) noted that the definition of the social responsibility of organizations includes openness and transparency of organizations as well as stakeholders' wishes and expectations. The social responsibility of organizations do not have specific constant standards and they may vary with each generation and in different cultures (Daugherty, 2001). Lithuania sector of economic activity is related to cars purchase, sale and other processes because of their prevalence and position of the scale is often referred to the "national" business. In Marijampole, there are about 60 percent of working-age people who are directly or indirectly related to the car business. In Lithuanian car business the division of labor is noticed:

one company buys cars in Western countries, other repairs, and the third company sales. The secondary car market is also formed in the country. Car business create added value not only to traders, the profit is also received by car repairers, hotel owners, cafes, restaurants, service stations, etc. (Kovalev, Snieska, Simanavicius 2009). More detailed structure of this economical system is important as the part of the car business structure of Lithuanian population that guarantees the additional jobs and creates added value given in Figure 3.

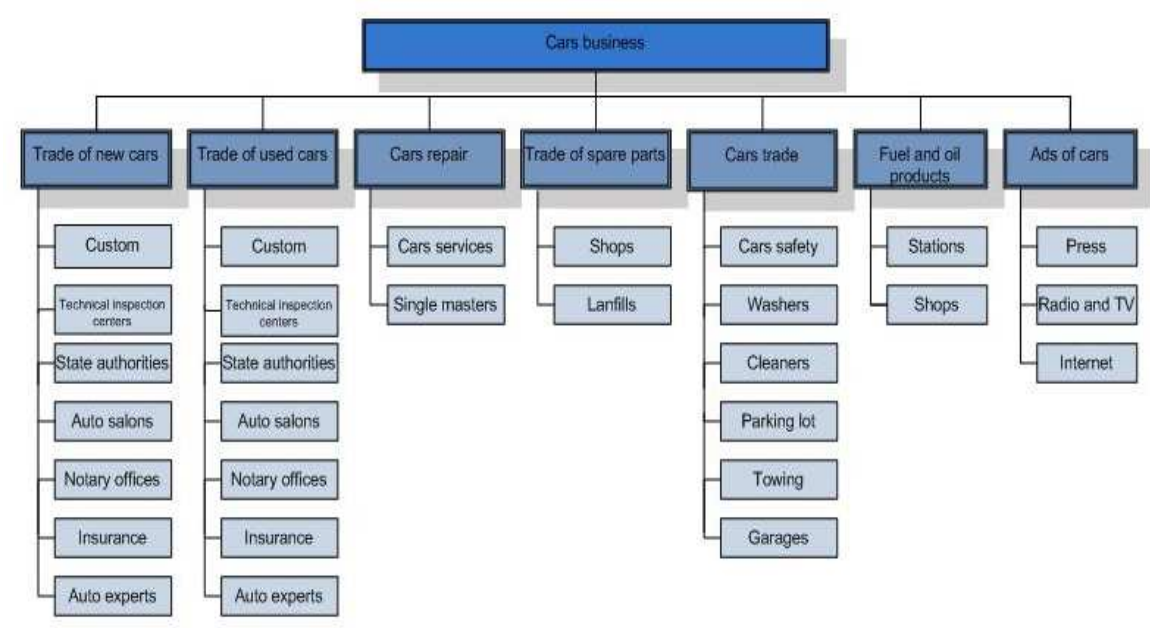

Fig 3. Car Business Structure in Lithuania 
The car market in Lithuania is divided into:

- $\quad$ market of new cars;

- $\quad$ market of used cars.

Due to its structural characteristics, the lack of social responsibility and a high risk degree of tax evasion, car business of economic activity was chosen for more detailed examination.
The evaluation of vehicle sale, repair and technical maintenance sector, its size, structure, taxes paid and other operations indicators shows that the largest part of the sector consists of companies engaged in motor vehicle technical maintenance and repair: in 2009 these companies accounted for 42.0 percent (3499 firms). In 2009 motor vehicle trade business was implemented by 2958 companies that consist 35.5 percent of all sector companies (see Figure 4).

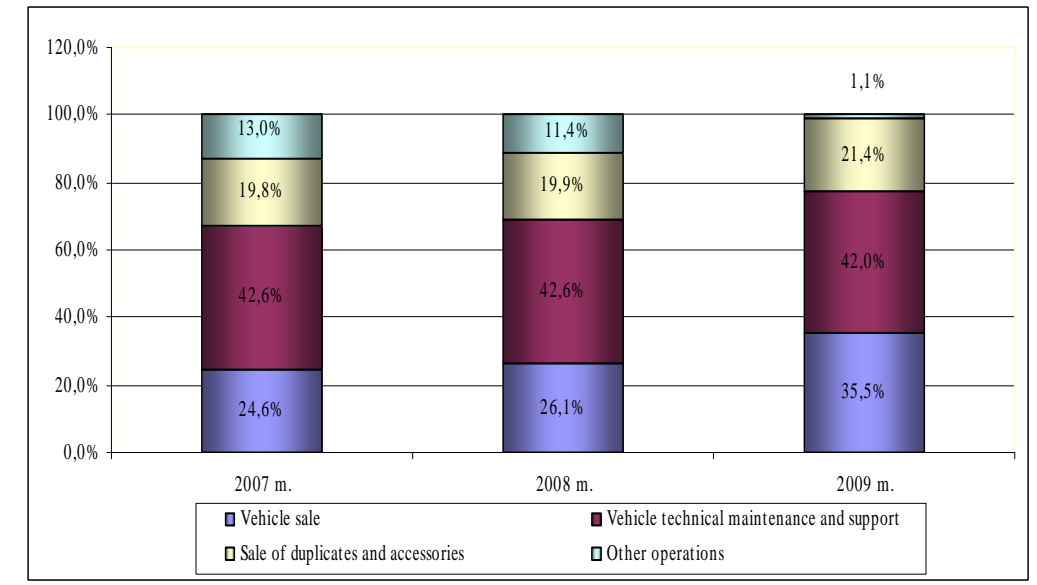

The data according to STA concluded by the authors

Fig 4. Evaluation of Vehicle Sale, Technical Maintenance and Repair Business Companies in Accordance With the Operations Implemented in 2007-2009

In 2009 it was registered 3541 VAT payers, it is 37.5 percent of all this group payers. There are 3387 legal persons (98.2 percent) and only 64 natural persons (1.8 percent).
Evaluation of the real extent of the car sale and repair business shows that there are little of the natural persons as VAT payers in the set of research. 


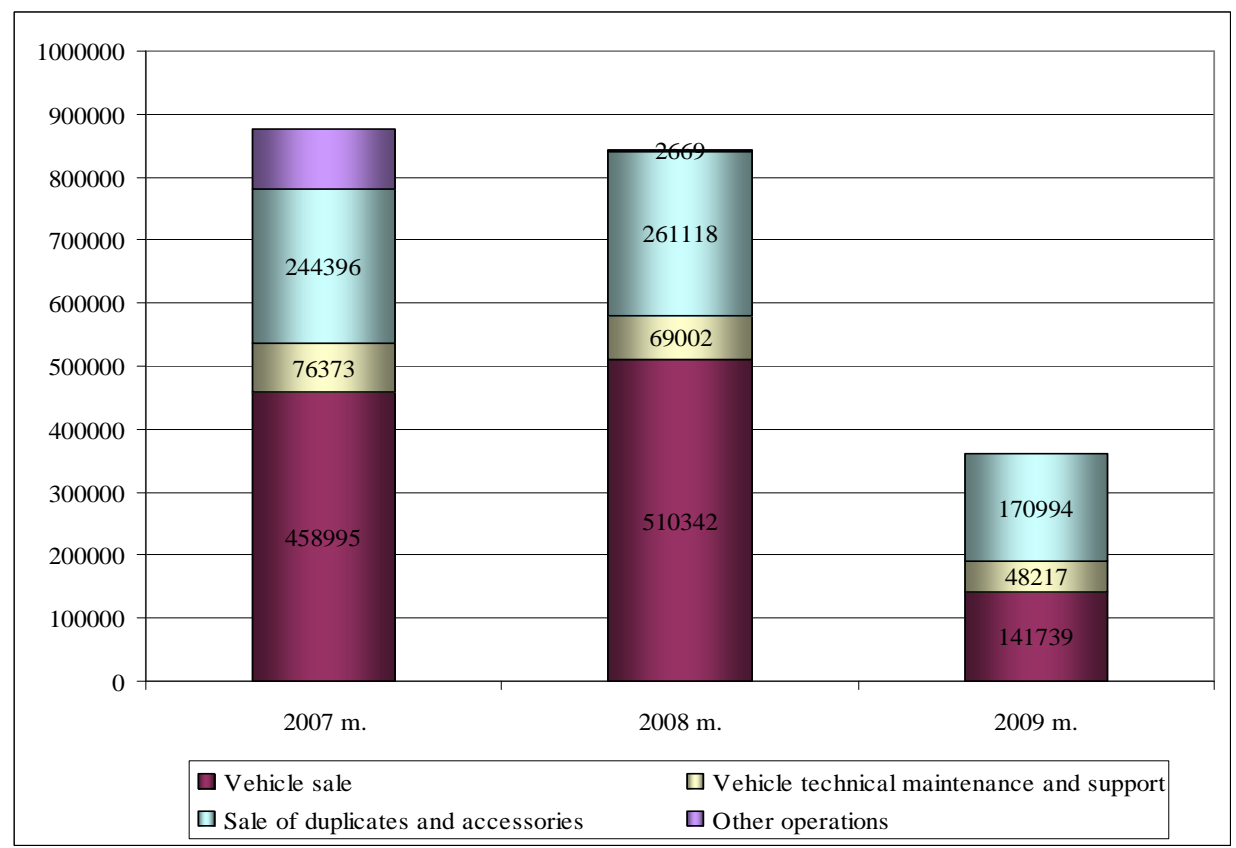

The data according to STA concluded by the authors

Fig 5. Evaluation of Taxes and Other Payments in Accordance with Operations in 20072009, Thousand of LTL

Taxpayers who declare and carry on motor vehicle sales, technical maintenance and repair operations paid 360.9 million LTL taxes and other payments in 2009 , it is 482.2 million LTL (57 percent) less than in 2008. In 2009 , most of the taxes were received from the sale of duplicate and accessories of motor vehicle business 47.4 percent (171 million LTL), though the companies of sales of duplicate and accessories business amounted to 21.4 percent of the entire sector enterprises that were analyzed.

The analysis of taxpayers structure has revealed that VAT payers (legal persons engaged in business) pay the largest share of all taxes, while payments shares of other taxpayers' is quite small. In 2009 legal persons who are VAT payers paid 99.7 percent of all VAT, income tax and personal income tax that are paid by the analyzed sector. This study has showed that non-VAT payers, who represent 62.5 percent of the total number of companies, do not pay any taxes to the budget.

Evaluation of the active VAT payers has showed that in 2009, compared with 2008 , the growth of the sector came to an end. 
Table 1: Indicators of VAT Payers during 2007-2009

\begin{tabular}{|l|l|l|l|}
\hline Indicators & 2007 & 2008 & 2009 \\
\hline TOTAL & & & \\
\hline 1. Sales, thousand of LTL & 9856046 & $\begin{array}{l}9 \\
615\end{array}$ & 4933727 \\
\hline 2.Added value, thousand of LTL & 1464396 & $\begin{array}{l}1 \\
180\end{array}$ & 1707076 \\
\hline 3.VAT paid, thousand of LTL & 658075 & 625561 & 258713 \\
\hline 4. Income tax paid, thousand of LTL & 61592 & 83515 & 16223 \\
\hline $\begin{array}{l}\text { 5. CIT (A class) paid, thousand of } \\
\text { LTL }\end{array}$ & 102872 & 132191 & 49061 \\
\hline 6. Number of employees monthly & 33133 & 32400 & 30305 \\
\hline 7. Number of taxpayers & 2827 & 3752 & 3541 \\
\hline
\end{tabular}

The data according to STA and SODRA concluded by the authors

We can see that in 2009 growth in the sector came to an end. All indicators of quality were worse compared with 2008. Value added, sales, paid VAT, income tax and CIT, the employment and number of taxpayers were decreased (see Table 1).

\section{Taxation Issues in the Process of the Used Motor Vehicles Sales}

The analysis has revealed that the companies of the motor vehicle sale pay most of the taxes to the budget in this sector over last three years (see Figure 5), but the sector of motor vehicles sale has a great part of undeclared activities (income) that makes it informal business. It happens because of the specificity of the business, frequent transactions in cash. Business process of cars sale is realized purchasing cars of various technical condition in foreign countries, mainly in the area of the European Union (hereinafter - EU). The majority of cars leave Lithuania after technical repair, mainly to Russia, Kazakhstan, Kyrgyzstan, Belarus, and the lower part of cars is sold to customers in Lithuania.

Key taxation issues and irregularities of this business process that are often faced by the taxpayers are:

- Used vehicle sales are not licensed, and it is relatively easy to engage this business for both companies and individuals. Due to the specifics of this business, a significant proportion of trade is taken by a population (individuals), for whom conditions have improved after Lithuania joined the EU. Most of cars are imported to Lithuania from the EU countries, but the customs do not capture the fact of their entry. It encourages both companies and individuals, who sell used cars from the EU countries, to hide the importation and sales of cars and revenue that was got.

- A number of individuals "intermediaries", who arrange or carry out the repair of imported cars or find customers and sell cars to them, are involved in the sale business of used cars. A direct transaction between the previous owner of the car from another, the EU state and a buyer, who was found in Lithuania, is registered not showing being of "intermediary". This business scheme of cars sale is mainly used by individuals that engaged in the business of cars sale. Such individuals often operate without business registration, declaration of income returns and payment of taxes.

- Large companies, which are VAT payers, are engaged in the business of vehicles sale as well as small businesses that are nonVAT payers and natural persons that have registered or have not their individual business. At the moment of used vehicles sales, the real value of transactions is hidden, making it difficult 
to determine when a taxpayer has to register for VAT purposes.

It is a frequent practice when the taxes, paid to the budget, are avoided by indicating decreased prices of selling used cars in transaction documents. The prices of cars for sale are set at the time of admission by adding the already reduced value of a car to the minimum mark-up, which is usually significantly less than the car-repair costs. Most of the imported cars are damaged, and according to the documents placed under the export they are exported without apparent irregularities, which lead to the conclusion that they were repaired in Lithuania. Since the value of cars for sale often differ little from the value of purchase, it must be concluded that the repair costs are not included in their selling price.

Summarized results of the research illustrate and base the extent of irregularities in Table 2. The study assumes that the data of imports from Switzerland and the United States reflects the most accurate used cars prices. New vehicles are mainly imported from such countries as China, Japan, and Russia and so on, so it is inappropriate to estimate their evaluation of used cars prices.

Considering the assumptions, it was found that in 2009 the average of used car value, which had been imported to Lithuania and declared, is equal to 9,326 LTL (1 EURO 3,45 LTL).

Table 2: The Import of Cars for Domestic Consumption in 2009

\begin{tabular}{|l|l|l|l|}
\hline $\begin{array}{l}\text { Name of the } \\
\text { country }\end{array}$ & $\begin{array}{l}\text { Number of } \\
\text { the Customs } \\
\text { BD in 2009 }\end{array}$ & $\begin{array}{l}\text { Statistical value in } \\
\text { 2009, thousand } \\
\text { LTL }\end{array}$ & $\begin{array}{l}\text { Average value of import } \\
\text { procedure in 2009, LTL }\end{array}$ \\
\hline Baltarussia & 838 & 10.526 & 12.561 \\
\hline Switzerland & 623 & 2.468 & 3.963 \\
\hline China & 2.424 & 24.460 & 10.091 \\
\hline Japan & 294 & 10.817 & 36.793 \\
\hline Hong Kong & 377 & 9.229 & 24.482 \\
\hline Russia & 1.401 & 13.037 & 9.306 \\
\hline Taiwan & 1.348 & 26.716 & 19.819 \\
\hline USA & 4.670 & 46.896 & 10.042 \\
\hline $\begin{array}{l}\text { Both Switzerland } \\
\text { and USA }\end{array}$ & 5.293 & 49.364 & 9.326 \\
\hline
\end{tabular}

The data according to STA and Customs Department concluded by the authors

Accomplishing the customs data analysis, it was considered that the customs export data accurately to reflect the real prices of used cars that leave the Republic of Lithuania. Using the data on exports of cars from Table 3 , it was considered that the average value of used car, which leaves Lithuania, is equal to 8.355 LTL. 
Table 3: Statistical Information on Car Exports in 2009

\begin{tabular}{|l|l|l|l|}
\hline Name of Customs procedure & $\begin{array}{l}\text { Number of BD } \\
\text { Customs in 2009 }\end{array}$ & $\begin{array}{l}\text { Statistical value } \\
\text { in 2009, } \\
\text { thousand LTL }\end{array}$ & $\begin{array}{l}\text { The average value } \\
\text { of export's } \\
\text { procedure in } \\
\text { 2009, LTL }\end{array}$ \\
\hline Forfeit export & 162.666 & 1.261 .373 & 7.754 \\
\hline Reexport & 18.738 & 205.794 & 10.982 \\
\hline Reexport after storage & 3.270 & 75.780 & 23.174 \\
\hline $\begin{array}{l}\text { Totall according to export } \\
\text { procedure: }\end{array}$ & 184.674 & 1.542 .947 & 8.355 \\
\hline
\end{tabular}

The data according to STA and Customs Department concluded by the authors

Analysis helps to set the values of cars, which are imported to and exported from Lithuania. They differ little. It shows that the subjects of cars sale have not declared the real added value that had been created, have induced the informal economy and have increased the degree of the economic crisis. The taxation issue that was mentioned earlier is based on estimates made during analysis, that the average values of cars, which are imported and exported, are relatively low and do not match real market prices.

\section{The Management Model of Tax Risk}

Due to new business, accounting and international cooperation conditions, changes in tax administration, new legislation (related to Lithuania's accession to the EU as well), there is an increase in the numbers of tax documents and tax procedures and requirements for data quality (Daugirda, 2007). Because of the reasons enlisted, the quantity of the issued / received documents is changing in all areas of business sectors.

Tax administrator contributes to the reduction of administrative tax cost and the increase of budget tax revenue, disposing properly information of e. databases (see Table 4) declared by taxpayers in various ways (electronic - in the e. format declarations and reports, and the classic in the paper based declarations and reports) and converted to electronic forms. 
Table 4: E. Databases of Information about Taxpayers

\begin{tabular}{|c|c|c|c|c|c|c|}
\hline Databases & Software & $\begin{array}{l}\text { What main data } \\
\text { are kept }\end{array}$ & $\begin{array}{l}\text { Principle } \\
\text { of data } \\
\text { provision }\end{array}$ & $\begin{array}{l}\text { Men- } \\
\text { tror- } \\
\text { ing by }\end{array}$ & $\begin{array}{l}\text { Inte- } \\
\text { rope- } \\
\text { rabi-lity }\end{array}$ & $\begin{array}{l}\text { Main strengthen / } \\
\text { weakness }\end{array}$ \\
\hline $\begin{array}{l}\text { IMIS } \\
\text { (integrated } \\
\text { tax } \\
\text { information } \\
\text { system) }\end{array}$ & $\begin{array}{l}\text { Oracle } \\
\text { forms, Java, } \\
\text { Oracle DB } \\
\text { Microsoft }\end{array}$ & $\begin{array}{l}\text { All data that are } \\
\text { needed for tax } \\
\text { administration. } \\
\text { (Registration, } \\
\text { declaration, } \\
\text { accounting, } \\
\text { payments, staff, } \\
\text { checks, appeals } \\
\text { and so on) }\end{array}$ & Not public & STA & $\mathrm{BO}$ & $\begin{array}{l}\text { The agility and the } \\
\text { ability to change the } \\
\text { relevant information / } \\
\text { A lot of data showcases } \\
\text { are created, it is difficult } \\
\text { to link and aggregate } \\
\text { their data }\end{array}$ \\
\hline MOKSI & $\begin{array}{l}\text { Net, } \\
\text { OracleDB }\end{array}$ & $\begin{array}{l}\text { Data about Tax } \\
\text { payers' risk } \\
\text { violations of the } \\
\text { laws }\end{array}$ & $\begin{array}{l}\text { Not public } \\
\text { access }\end{array}$ & STA & $\mathrm{BO}$ & $\begin{array}{l}\text { Facilitate the Tax } \\
\text { administrator's work } \\
\text { with risky taxpayers / } \\
\text { Difficult navigation }\end{array}$ \\
\hline $\begin{array}{l}\text { Database of } \\
\text { Customs } \\
\text { Department }\end{array}$ & $\begin{array}{l}\text { SAS - } \\
\text { Taxud } \\
\text { Microsoft }\end{array}$ & $\begin{array}{l}\text { Data about import } \\
\text { and export } \\
\text { procedures of } \\
\text { operators, goods, } \\
\text { buyers and sellers }\end{array}$ & $\begin{array}{l}\text { Not public } \\
\text { access }\end{array}$ & $\begin{array}{l}\text { Cus- } \\
\text { toms } \\
\text { depart } \\
\text { ment }\end{array}$ & IMIS & Difficult navigation \\
\hline $\begin{array}{l}\text { Database of } \\
\text { SODRA }\end{array}$ & $\begin{array}{l}\text { Oracle } \\
\text { forms, } \\
\text { Oracle DB } \\
\text { Mircrosoft }\end{array}$ & $\begin{array}{l}\text { Data about salary } \\
\text { and withheld and } \\
\text { paid taxes of } \\
\text { insured recipients } \\
\text { paid by state's } \\
\text { social fund }\end{array}$ & $\begin{array}{l}\text { Not public } \\
\text { access }\end{array}$ & $\begin{array}{l}\text { SOD- } \\
\text { RA }\end{array}$ & IMIS & $\begin{array}{l}\text { Data are given and } \\
\text { updated only to } \\
\text { quarters. }\end{array}$ \\
\hline $\begin{array}{l}\text { Databases of } \\
\text { population } \\
\text { registry }\end{array}$ & $\begin{array}{l}\text { Oracle } \\
\text { forms, } \\
\text { Oracle DB }\end{array}$ & $\begin{array}{l}\text { Information about } \\
\text { registry data of } \\
\text { country's } \\
\text { population } \\
\text { (personal code, } \\
\text { name, surname, } \\
\text { registration } \\
\text { address) }\end{array}$ & $\begin{array}{l}\text { Public data } \\
\text { in part }\end{array}$ & $\begin{array}{l}\text { Minist } \\
\text { ry of } \\
\text { Interri } \\
\text { or }\end{array}$ & IMIS & $\begin{array}{l}\text { Facilitate the Tax } \\
\text { administrator's work } \\
\text { with risky tax-payers }\end{array}$ \\
\hline $\begin{array}{l}\text { Database of } \\
\text { legal persons } \\
\text { registry }\end{array}$ & $\begin{array}{l}\text { Oracle } \\
\text { forms, } \\
\text { Oracle DB }\end{array}$ & $\begin{array}{l}\text { Information about } \\
\text { registry data of } \\
\text { legal persons } \\
\text { (legal person's } \\
\text { code, name, } \\
\text { registry address, } \\
\text { information given } \\
\text { by head, bank } \\
\text { account, operating } \\
\text { licenses and } \\
\text { permits) }\end{array}$ & $\begin{array}{l}\text { Public data } \\
\text { in part }\end{array}$ & TM & IMIS & $\begin{array}{l}\text { Facilitate the Tax } \\
\text { administrator's work } \\
\text { with risky tax-payers }\end{array}$ \\
\hline $\begin{array}{l}\text { Database of } \\
\text { international } \\
\text { information } \\
\text { exchanges }\end{array}$ & $\begin{array}{l}\text { Gateway } \\
\text { Microsoft }\end{array}$ & $\begin{array}{l}\text { Information about } \\
\text { exchanges of } \\
\text { information with } \\
\text { foreign state tax } \\
\text { administrators } \\
\text { (sent and received } \\
\text { requests for } \\
\text { information and } \\
\text { responses to } \\
\text { inquiries) }\end{array}$ & Not public & STA & BO & $\begin{array}{l}\text { Facilitate the Tax } \\
\text { administrator's work } \\
\text { with risky tax-payers } \\
\text { globally because it } \\
\text { includes the EU space / } \\
\text { Incorrect (with } \\
\text { mistakes) information, } \\
\text { disorders of connection } \\
\text { and inform. system }\end{array}$ \\
\hline
\end{tabular}




\begin{tabular}{|c|c|c|c|c|c|c|}
\hline $\begin{array}{l}\text { VIES (VAT } \\
\text { Information } \\
\text { Exchange } \\
\text { system) }\end{array}$ & $\begin{array}{l}\text { Oracle } \\
\text { forms, } \\
\text { Oracle DB }\end{array}$ & $\begin{array}{l}\text { Register of EU } \\
\text { Member States } \\
\text { (hereinafter - ES } \\
\text { MS) VAT } \\
\text { information given } \\
\text { by taxpayers } \\
\text { Declared goods } \\
\text { supplies of ES MS } \\
\text { VAT taxpayers to } \\
\text { other ES MS. }\end{array}$ & $\begin{array}{l}\text { Not public } \\
\text { access }\end{array}$ & EC & IMIS, BO & $\begin{array}{l}\text { It is possible to get } \\
\text { information from EC MS } \\
\text { / Inappropriate (with } \\
\text { errors) information, } \\
\text { failure of } \\
\text { communication and } \\
\text { inform. systems }\end{array}$ \\
\hline GYPAS & $\begin{array}{l}\text { Oracle } \\
\text { forms, } \\
\text { Oracle DB }\end{array}$ & $\begin{array}{l}\text { Information about } \\
\text { the tax declaration } \\
\text { of population }\end{array}$ & $\begin{array}{l}\text { Not public } \\
\text { access }\end{array}$ & STA & IMIS, BO & $\begin{array}{l}\text { Facilitate the Tax } \\
\text { administrator's work } \\
\text { with risky taxpayers }\end{array}$ \\
\hline $\begin{array}{l}\text { AIS (Excise } \\
\text { Duties } \\
\text { information } \\
\text { system) }\end{array}$ & $\begin{array}{l}\text { PHP, .Net, } \\
\text { Oracle DB }\end{array}$ & $\begin{array}{l}\text { EMCS and data } \\
\text { needed to } \\
\text { administrate } \\
\text { excise taxes }\end{array}$ & $\begin{array}{l}\text { Not public } \\
\text { access }\end{array}$ & & IMIS, BO & $\begin{array}{l}\text { The possibility to get } \\
\text { information from the } \\
\text { EU VN / } \\
\text { Incorrect (with } \\
\text { mistakes) information, } \\
\text { the disorders of } \\
\text { connection and inform. } \\
\text { system }\end{array}$ \\
\hline $\begin{array}{l}\text { Real Estate } \\
\text { registry }\end{array}$ & $\begin{array}{l}\text { Oracle } \\
\text { forms, } \\
\text { Oracle DB }\end{array}$ & $\begin{array}{l}\text { Information about } \\
\text { real estate of } \\
\text { natural and legal } \\
\text { persons }\end{array}$ & $\begin{array}{l}\text { Public data } \\
\text { in part }\end{array}$ & TM & $\begin{array}{l}\text { via } \\
\text { Internet }\end{array}$ & $\begin{array}{l}\text { Facilitate the Tax } \\
\text { administrator's work } \\
\text { with risky tax-payers }\end{array}$ \\
\hline $\begin{array}{l}\text { TDS } \\
\text { Interdepart } \\
\text { mental tax } \\
\text { data storage }\end{array}$ & $\begin{array}{l}\text { Business } \\
\text { Objects (BO) }\end{array}$ & $\begin{array}{l}\text { Aggregate IMIS } \\
\text { and information } \\
\text { from other } \\
\text { databases of STA }\end{array}$ & $\begin{array}{l}\text { Not public } \\
\text { access }\end{array}$ & GOV & $\begin{array}{l}\text { IMIS, } \\
\text { TIMS, } \\
\text { MOKSI, } \\
\text { GYPAS, } \\
\text { AIS, } \\
\text { VIES, } \\
\text { Depart- } \\
\text { ment of } \\
\text { Statistics } \\
\text {, FNTT }\end{array}$ & $\begin{array}{l}\text { Some data are updated } \\
\text { too slowly, some errors } \\
\text { are possible. }\end{array}$ \\
\hline $\begin{array}{l}\text { EDS } \\
\text { E. } \\
\text { declaration } \\
\text { system }\end{array}$ & $\begin{array}{l}\text { Net } \\
\text { applications } \\
\text { and MS SQL } \\
\text { DB }\end{array}$ & $\begin{array}{l}\text { Given/declared } \\
\text { data by taxpayers } \\
\text { (natural and legal } \\
\text { persons) }\end{array}$ & $\begin{array}{l}\text { Public } \\
\text { access/ } \\
\text { using the } \\
\text { data in } \\
\text { part }\end{array}$ & STA & IMIS, BO & $\begin{array}{l}\text { Attractive access to } \\
\text { external users, } \\
\text { constantly improved. / } \\
\text { There is no timestamp, } \\
\text { and it is possibility of } \\
\text { technical problems } \\
\text { associated with peak } \\
\text { flows of information at } \\
\text { the time of general } \\
\text { declaration. }\end{array}$ \\
\hline $\begin{array}{l}\text { AIS RAAS } \\
\text { Audit's } \\
\text { information } \\
\text { system } \\
\text { Subsystem } \\
\text { of risk } \\
\text { analysis and } \\
\text { sample } \\
\end{array}$ & SQL & $\begin{array}{l}\text { Automatical } \\
\text { evaluation of } \\
\text { taxpayers' risk is } \\
\text { made }\end{array}$ & $\begin{array}{l}\text { Not public } \\
\text { access }\end{array}$ & STA & IMIS, BO & $\begin{array}{l}\text { Expedition and integrity } \\
\text { of information, specific } \\
\text { tool to analyze the data } \\
\text { about taxpayers and } \\
\text { evaluate their risk. }\end{array}$ \\
\hline $\begin{array}{l}\text { AIS BAPS - } \\
\text { Audit's } \\
\text { information } \\
\text { system } \\
\text { Subsystem } \\
\text { of general } \\
\text { audit's } \\
\text { support }\end{array}$ & SQL & $\begin{array}{l}\text { Taxpayers' } \\
\text { information that is } \\
\text { in e-case is used } \\
\text { during control of } \\
\text { taxpayers }\end{array}$ & $\begin{array}{l}\text { Not public } \\
\text { access }\end{array}$ & STA & IMIS, BO & $\begin{array}{l}\text { Expedition and integrity } \\
\text { of information }\end{array}$ \\
\hline
\end{tabular}


The effective use of available information is increased by its linkage with other institutions' collected and stored e. information on a taxpayer and the sectoral indicators of aggregated economic operations, etc. Management of information from different source of government e. data, analysis in different view, using e. data collection / analysis and risk management tools, allow to improve the tax collection process and to respond to the information market and the risk degrees of change promptly, establishing strategies and measures to influence the undesirable results. The management model of tax risk is used by a tax administrator, in order to improve efficiency of risk management and tax collection using the scientific methods (Graham, Rogers, 2002).

This is especially true in the phase of slowing economic and at the period of crisis, when the informal economy is getting huge dimensions.

The SME environment is to improve through modern information tools and technologies. The management model of tax risk (see Figure 6) and its operating principles are proposed to curb the black economy identifying risky taxpayers under the probability of tax evasion. Following the analysis of country's economic sector, it is indenfied the most risky economic sector in which there is a high likelihood of tax evasion. Using the principled criterias of prie-selected risk in the indentified sector "target taxpayers", group is selected and the further tax analysis is directed to this group.

Seeking the most representative results and the highest degree of reliability in the fourth stage of the model, different and independent sources of information, which data will be used for further analysis, are chosen to carry out the processes of model operation.

During the fifth step of the process, each taxpayer and his economic activity is estimated according to the algorithm and some of the specific risk characteristics defined by the needs.

It is the significant part of evaluation process, because the taxpayers, who meet the set criteria, are selected for the further analysis. A certain criterion, in accordance with the attribute values with the dimension of risk level, expressed as the number, (see Table 6) is assigned to a taxpayer in the more difficult version of the selection process. In the sixth stage, the extent of risk is estimated, it is a minimum risk level. This process plays the role of original filter, which exercises initial selection of the most risky taxpayers, rejecting irrelevant taxpayers. It consists of assumptions to use resources for the enurance of processes more costeffectively. 


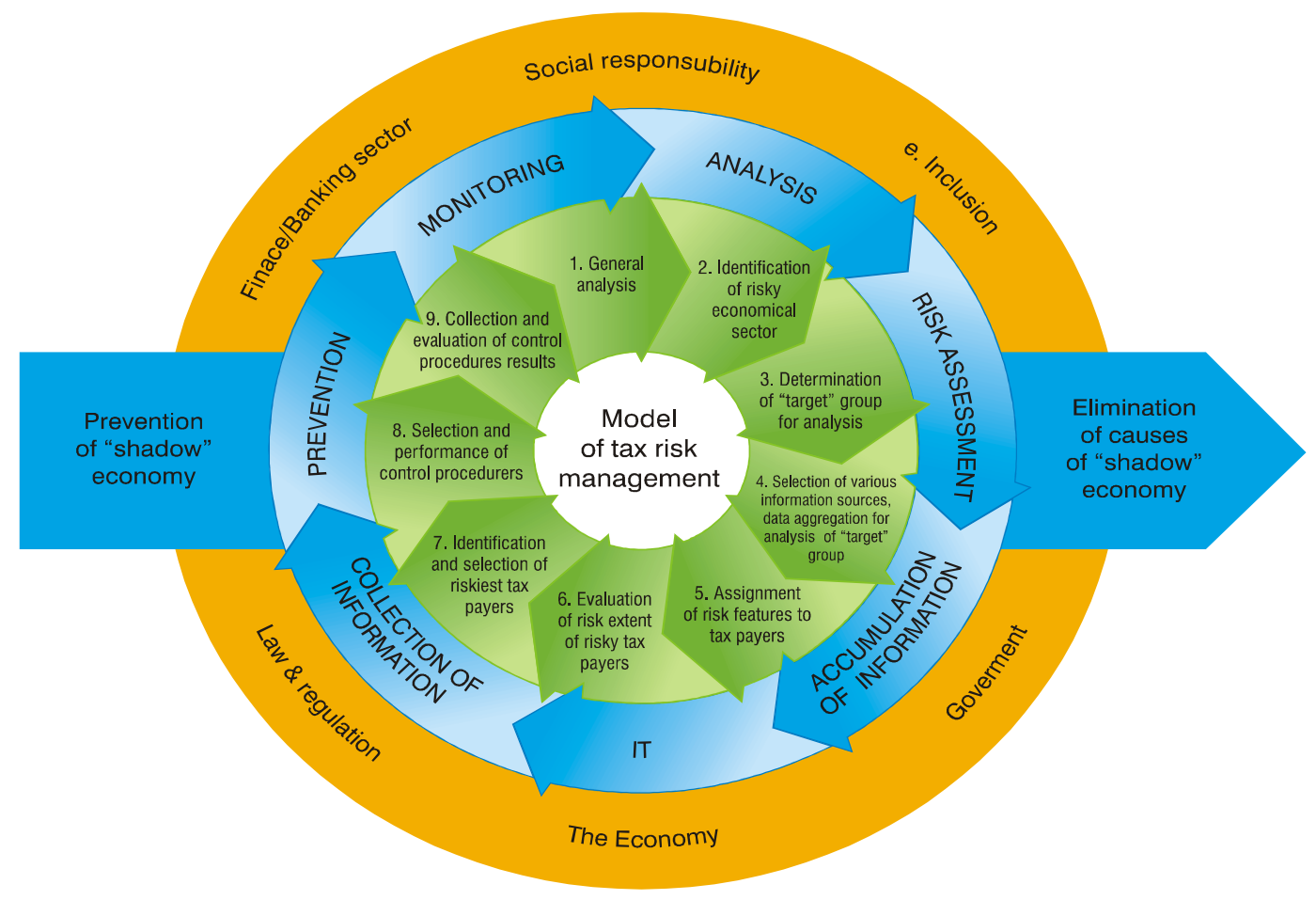

Fig 6. Management Model of Tax Risk

In the seventh management model of tax risk process, the obtained data is analysed and the risky taxpayers are identified. If a risk score is allocated to a certain fulfillment with the risk character, the most risky persons will be those persons who obtained the maximum scores. Otherwise the most risky taxpayers must comply with all or with the most significant risk features, distinguished in the fourth stage. It is also possible usage of mixed-risk assessment of those options, e. g. risk scores are calculated only in cases where taxpayers meet with a certain specific risk attributes and the like. In the penultimate process of operation, model control procedures are selected and implemented, it is actions of taxpayers' control. At the end of the process, the results of control procedures are collected and evaluated, and the evaluation of a total process of the risk management is carried out. The obtained results allow to identify the effectiveness of model and its components to plan the needs of new control procedures and the expected efficiency that allows for a constant update and improvement of the model operation.

\section{The Tax Model of Risk Management Adapted in Practice}

Illustrating the practical application of the model, the example in the industry sector of motor vehicles' sale and maintenance with the target group of natural persons was chosen because of their risky characteristics. The different sources were chosen to analyze this group: the Customs data (it is information about the Customs' procedures for export made by taxpayers) and the data of STA (it is registered data, declared and paid taxes of taxpayers). 
Table 5: Risk Criteria for Use of Taxpayers' Risk Assessment for Making No Payments of VAT

\begin{tabular}{|l|l|}
\hline $\begin{array}{l}\text { Serial } \\
\text { number }\end{array}$ & Description of criteria \\
\hline 1 & $\begin{array}{l}\text { In } 2009 \text { more than } 5 \text { procedures of vehicle's export was } \\
\text { implemented }\end{array}$ \\
\hline 2 & $\begin{array}{l}\text { The business of motor vehicles' sale (individual) was not } \\
\text { registered }\end{array}$ \\
\hline 3 & Not registered as VAT payer \\
\hline 4 & $\begin{array}{l}\text { Did not submit an annual declaration of income for the 2008 } \\
\text { 2009 or did not submit income of individual business in the } \\
\text { declaration }\end{array}$ \\
\hline
\end{tabular}

Concluded by the authors

The risk of each individual is assessed according to risk characteristics, presented in Table 5. All attributes from Table 5 are significant, and therefore for further analysis, only those taxpayers, who comply with all four risk criteria, are selected. The geographical distribution of natural persons to fulfill the minimum risk scale according to regions of the country is given in Figure 7.

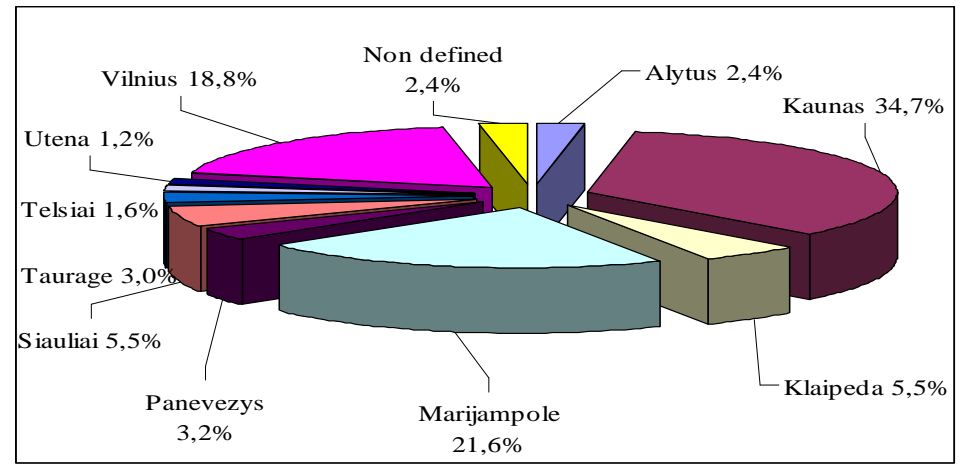

Fig 7. The Distribution of Analyzed Subjects by Counties

Analyzing research data (look at Figure 7 and Table 6), it was found that the biggest numbers of risky taxpayers are in the counties of Kaunas and Marijampole (34.7percent and 21.6 percent respectively).

The significance of potential risk in these regions is justified by the total value of procedures for the export, carried out in each region, given in the column 8 of Table 6. In counties of Kaunas and Marijampole, there is the biggest extent of undeclared and unpaid VAT as there is the largest export of vehicles. The average number of procedures for the export of vehicles, carried out by one taxpayer, is given in the column 6 of Table 6 . The taxpayers of Kaunas County carried out about 19.9 procedures for the export and Marijampole - 35.9 procedures in 2009. These average indicators are selected as a primary selection filter. The natural persons, who carry out more than the above-mentioned average number of procedures for the export, are selected on the basis of control procedures. 
Table 6: The Vehicles to Export Data of Natural Persons, Not Registered Individual Business and Pursued More Than 5 Export Procedures

\begin{tabular}{|l|l|l|l|l|l|l|l|l|}
\hline District & \multicolumn{2}{|l|}{$\begin{array}{l}\text { The number } \\
\text { of natural } \\
\text { persons }\end{array}$} & \multicolumn{2}{l|}{$\begin{array}{l}\text { The number of } \\
\text { export } \\
\text { procedures }\end{array}$} & \multicolumn{2}{l|}{$\begin{array}{l}\text { The average } \\
\text { number of } \\
\text { export } \\
\text { procedure }\end{array}$} & \multicolumn{2}{l|}{$\begin{array}{l}\text { Export value, } \\
\text { thousand LTL }\end{array}$} \\
\hline Year & 2009 & 2008 & 2009 & 2008 & 2009 & 2008 & 2009 & 2008 \\
\hline 1 & 2 & 3 & 4 & 5 & 6 & 7 & 8 & 9 \\
\hline Alytus & 12 & 8 & 130 & 154 & 10,8 & 19,3 & 452 & 700 \\
\hline Kaunas & 172 & 181 & 3417 & 3683 & 19,9 & 20,3 & 2374 & 3130 \\
\hline Klaipeda & 27 & 15 & 335 & 249 & 12,4 & 16,6 & 140 & 472 \\
\hline $\begin{array}{l}\text { Marijampol } \\
\text { e }\end{array}$ & 107 & 116 & 3836 & 3884 & 35,9 & 33,5 & 1899 & 2132 \\
\hline Panevezys & 16 & 19 & 190 & 301 & 11,9 & 15,8 & 91 & 482 \\
\hline Siauliai & 27 & 32 & 322 & 454 & 11,9 & 14,2 & 443 & 1403 \\
\hline Taurage & 15 & 29 & 155 & 346 & 10,3 & 11,9 & 260 & 1423 \\
\hline Telsiai & 8 & 7 & 67 & 72 & 8,4 & 10,3 & 40 & 87 \\
\hline Utena & 6 & 4 & 48 & 29 & 8,0 & 7,3 & 37 & 34 \\
\hline Vilnius & 93 & 48 & 922 & 608 & 9,9 & 12,7 & 692 & 892 \\
\hline Not defined & 12 & 34 & 228 & 427 & 19,0 & 12,6 & 85 & 320 \\
\hline TOTAL: & 495 & 493 & 9650 & 10207 & 19,5 & 20,7 & 6513 & 11079 \\
\hline
\end{tabular}

The data according to STA and the Customs Department concluded by the authors

Discussing the results of actions carried out in control, the following key focus can be identified:

- It is provided that some taxpayers have denied export procedures, explaining that it had misused their personal data and / or lost documents. The responsible law enforcement authorities were informed of such cases;

- It is found that some taxpayers have not declared income, provided required tax returns.

The follow-up control action to the taxpayers who did not agreed to correct the identified weaknesses in good faith has been taken by the creditor and the unpaid taxes, fine and penalties have been reckoned in.

Empirical studies in the practical application results of the given model showed that the proposed principle of model is efficient and effective to help accurately identify and control procedures refered to taxpayers with increased risk of tax evasion. The authors assert that this model can be used in future tax authorities as a significant tool that helps to optimize and increase the efficiency of the tax risk management. This is an important basis to ensure the tax revenue collection to the state budget especially at the moment of economic hardship conditions. It is also worth to mention that the practical results of the model applications have been confirmed the STA estimation of the black economy officially - the STA estimates that the black economy represents 25-32 percent of the national economy's GDP. However, the proposed model does not give the calculation of the black economy, that is why it is needed to continue the further expansion of the model, which can be used not only for the assessment of the tax risk but also for the broader calculations.

\section{Conclusions}

1. Today it is expected that organizations does not only seek to get profit but also act ethically, socially responsible and humanely in the fields of the civil society and the environment. Business is not an isolated body, it operates in the society, 
that is why society's problems are business issues too and the problems of one interested party affect other stakeholders as they are all interrelated. In order to achieve the best business results to organization and other interested parties, organization must act ethically and socially responsible. Ethical and socially responsible behavior gives to business a competitive advantage and long-term profitability as well as contributes to the sustainable development.

2. Distinctive features of social economy are direct public participation creating added value or public goods, the voluntary and the activity of social enterprises. On the other hand, the social economy, as the private business sector or the public sector, includes employment, financial flows, property, rent, trade, and other activities.

3. The management of tax risk to control the sector of vehicles' sale is needed for several reasons. The control of this sector has to be implemented because of its great influence on regional economic conditions, and also for the specific business characteristics and the high volume of informal business. In the third part of the research the average declared values of imported and exported from Lithuania cars are calculated. It confirms the being of black economy in the mentioned economic sector and the taxation issues on reduced prices and hidden value-added in the transaction of cars' sale.

4. In this article the authors suggest to use the e. evaluation model of tax risk to control the management of tax risk. The model is based on various sources of information, that combine data from e. databases, the analysis of joined data, selection of risky taxpayers and monitoring operations used by a tax authority. The creation of preventive mechanism and the maintenance of its functions require a certain part of resources that could be used for the promotion of a collective or selective product. The usage of the enforced mechanism increases the concentration degree of the interest groups that influence the power of strategic decision-makers and the provision growth of the collective products.

5. The empirical study proved that the suggested model is efficient and effective. It leads to the suggestion to use this model as a significant tool for a tax authority that allows optimizing and increasing the management effectiveness of tax risk. The optimization of financials and labor resources for monitoring activities enables to react, initiates changes in the tax legislative base, generates the collection of additional hidden revenue to the budget and contributes to the clarification of the business environment.

6. In scientific studies, the issues of the social responsibility and the development of risk management models are analyzed separately and a more detailed analysis of the impact of social responsibility to the risk management models has not been detected though they are certainly relevantly related. Further, research that reveals the factors of the risk management models for the creation of factors and linkages, the impact of contemporary society in all qualitative and quantitative levels are relevant and necessary.

7. Suggested model that has been tested in practice by the authors is excluded for its principles and the use of IT. In the first stage, tax system and tax risk, that allow concentrating and identifying the greatest risks to the tax system examining it on the macro level, reviewed and analyzed. In the second stage, a tax risk identification process created by the authors that allows identifying the risks of certain specific tax segments is applied. The third stage suggested a tax risk management model that identifies the specific risks accurately, assesses its level and suggests appropriate control measures. A very important feature of the suggested system is the feedback that is guaranteed at each stage. It allows adjusting and improving operation of each stage. 


\section{References}

Abrema, Activity Based Risk Evaluation Model of Auditing (2008). Australian Educational Research Pty Ltd, 1998. Retrieved October 11, from http://www.abrema.net/abrema/materiali ty_g.html.

Buškevičiūtè, E. A. (2003). Mokesčių sistema, Kaunas, Technologija.

Buškevičiūtè, E. A. Leškevičiūtė (2008). 'Rizikos Valdymas Draudimo İmonèse,' in Taikomoji ekonomika: sisteminiai tyrimai, T. 2, no 2, pp. 59-79. ISSN 1822-7996.

Clifford W. Smith \& René M. Stulz. (1985). "The Determinants of Firms' Hedging Policies," Journal of Financial and Quantitative Analysis, 20:391-405 Cambridge University Press doi:10.2307/2330757.

Čiegis, R. \& Grundey, D. (2005). 'Culture of Sustainability Gets its Momentum in Lithuania,' in Transformations in Business and Economics, vol. 4, no. 2. pp. 176-179. ISSN 1648-4460.

Daugirda, D. (2007). 'System of Electronic Declaration in Lithuania: Effective Administration,' in the Theoretical and Practical Journal Public Administration, vol. 3, no. 15, pp. 9-13. ISSN 1648-4541.

Genete, L. D. \& A. Tugui. (2008). 'Particularities of Audit Planning in Ecommerce,' in Communications of the IBIMA. vol. 5. ISSN: 1943-7765.

Graham, R. J. \& Rogers, D. A. (2002). "Do Firms Hedge in Response to Tax Incentives?," The Journal of Finance Volume 57, Issue 2, pages 815-839, April. DOI: 10.1111/1540-6261.00443

Grundey, D. (2009). 'Challenging Economic Growth and Management Innovations: rec. konf.: Economic Challenges of the 21st Century: Poland-European Union-the World,' in Transformations in business and economics, vol. 8, no. 1, pp. 191-194. ISSN 1648-4460.
Grundey, D. \& Mažeika, A. (2009). 'The Influence of Taxing System on Small and Medium-Sized Businesses,' in Transformations in Business and Economics, vol. 8, no. 1, pp. 187-190. ISSN 1648-4460.

Guzavicius, A. (2009). 'Interest Groups and Social Economy,' in Technologija Economics and Management, Kaunas, no. 14 pp. 251255. ISSN 1822-6515.

Hood, J. \& Kelly, S. (V). "The Emergence of Public Sector Risk Management: The Case of Local Authorities in Scotland," Policy Studies, X, vol. 20, no.4, pp. 273-283.

Kabašinskas, J., Toliatienè, I. Auditas, Vilnius: Aimužè, 1997. 382 pp. ISBN 9986-430-24-0.

Lando D. Credit Risk Modeling (2009). Handbook of Financial Time Series, Part 5, Pages 787-798. DOI: 10.1007/978-3-54071297-8_35

Laukaitis, E. \& Navickas, V. (2003). 'Šešèlinès Ekonomikos Egzistavimo Priežastys Ir Tendencijos. Inžinerinė Ekonomika,' Kaunas, Technologija, , no. 3 (34), pp.61-67.

Mackay, I. L. \& Sweeting, R. C. (2003). 'Perspectives on Integrated Business Risk Management (BRM) and the Implications for Corporate Governance,' in Corporate Governance: An International Review, X(4), pp. 367-375.

Mackevičius, J. Audito teorija ir praktika. Monografija, Vilnius, Lietuvos mokslas, 1999, 699 pp. ISBN 9986-795-05-2.

Mažeika, A., Buginskis, V., Petrauskas, R., Satkauskas, R. (2009). 'Risk Management Systems in Business Processes of Contemporary Small and Medium-Sized Enterprises,' in Economics and Management, Kaunas, Technologija, vol. 14, pp. 186-192. ISBN 978-9955-25-662-5.

Melnikas, B. (2007). 'Globalization, Knowledge Based Society and EGovernance: Security Problems,' in the Theoretical and Practical Journal Public 
Administration, $\quad / 3$

pp. 53-64. ISSN 1648-4541.

(15),

Novošinskienė, A. (2000). 'Lietuvos Mokesčių Sistemos Analizė Ir Tobulinimas,' in Doctor disertation's abstract, Lietuvos Žemès Ūkio akademija.

O'Neil, J. M. \& Egan, J. (1992). 'Men's and Women's Gender Role Journeys: Metaphor for Healing, Transition, and Transformation,' in Gender issues across the life cycle, New York, Springer, pp. 107123.

Rimas, J. (2000). Vietiniai Mokesčiai, Kaunas, Technologija.

Stačiokas, R. (2003). 'Lietuva ir Europos Sąunga: Mokesčių Harmonizavimas,' in Ekonomika, no. 63.

Stačiokas, R. \& Rupšys, R. (2003). 'Audito Atranka: Statistinių Metodų Taikymas,' in Inžinerinè ekonomika, Kaunas, Technologija, no. 2(33), pp. 29-33. ISSN 1392-2785.

Stačiokas, R., Mažeika, A., Šerènienè, L. (2004). 'Mokesčių Sistemos Poveikis Verslui ir Jo Vertinimo Tendencijos,' in Ekonomika, Vilnius: Ekonomika, pp. 105-117. 